\title{
EFEKTIVITAS PENDEKATAN KONTEKSTUAL DALAM PEMBELAJARAN MENULIS TEKS NEGOSIASI
}

\author{
Yani Siti Asyani \\ Universitas Suryakancana Cianjur \\ E-mail: sitiasyani6@gmail.com
}

\begin{abstract}
This article discusses the effectiveness of a contextual approach to learning writing negotiating texts. The research was conducted to find out the influence and the result of learning to write negotiation text with contextual approach. The research method used is quasi experiment with One group Pretest-Posttest Design. The selected population is class X SMK Negeri 1 Bojongpicung with a sample of students of class X ATPH 1 amounted to 28 people. Data were collected using test, questionnaire, and observation techniques with test sheet, questionnaire, and observation. The results of the observation sheet indicate the active learners learn when using a contextual approach. From the test results, it is known that the average value of the initial test is 66.89 while the mean score of the final test is 87.64. After comparing the mean of the two test results, calculations were performed using the t-Test. The calculation result with t-test shows the tcount price is bigger than ttable price. The tcount price is 17.00 , while the ttable price at $\mathrm{db} 27$ for the 0.05 level of trust is 2.05 . Thus the proposed hypothesis can be accepted, ie the existence of a significant influence in the use of contextual approaches to the results of learning to write negotiation text. This shows the learning of writing negotiated text by applying a better contextual approach than without applying a contextual approach.
\end{abstract}

Keywords: effectiveness, contextual, negotiation.

\section{PENDAHULUAN}

Dunia pendidikan mengalami perkembangan yang cukup pesat. Perkembangan tersebut terjadi untuk meningkatkan mutu pendidikan agar semakin baik. Salah satu yang mengalami perkembangan dalam pendidikan adalah penggunaan pendekatan pembelajaran. Berbagai pendekatan pembelajaran terus diciptakan oleh para ahli seiring dengan berkembangnya zaman, hal tersebut bertujuan untuk lebih mengefektifkan kegiatan pembelajaran yang nantinya berpengaruh terhadap mutu pendidikan yang dihasilkan. Di masa ini pendekatan pembelajaran yang sering digunakan adalah pendekatan saintifik dan pendekatan kontekstual.
Pendekatan kontekstual adalah konsep pembelajaran dengan jalan membuat hubungan antara pengetahuan yang dipelajari dengan penerapannya dalam kehidupan sehari-hari. Pendekatan ini penting digunakan dalam pembelajaran, karena pendekatan ini melatih peserta didik mampu menerapkan dan menghubungkan apa yang dipelajari di sekolah untuk menghadapi problema yang dihadapi dalam kehidupan sehari-hari saat ini maupun yang akan datang. Jika digunakan dalam pembelajaran, pendekatan kontekstual dapat mempermudah siswa dalam belajar serta dapat membuat siswa belajar dengan baik, karena apa yang dipelajarinya berkaitan dengan apa sudah diketahuinya dan dikenal di sekelilingnya, seperti yang diungkapkan oleh John Dewey (1916) dalam Hosnan (2014: 267) bahwa "siswa akan belajar dengan baik jika apa yang dipelajari terkait dengan apa 
yang telah diketahui dan dengan kegiatan atau peristiwa yang terjadi di sekelilingnya". Karena pendekatan kontekstual dapat membuat siswa belajar dengan baik maka pendekatan ini dapat digunakan dalam materi pembelajaran yang berkaitan dengan keterampilan berbicara maupun keterampilan menulis.

"Menulis merupakan suatu kegiatan komunikasi berupa penyampaian pesan (informasi) secara tertulis kepada pihak lain dengan menggunakan bahasa tulis sebagai alat atau medianya" (Dalman, 2011:3). Menulis adalah salah satu dari empat keterampilan berbahasa yang produktif secara tulisan, tetapi dirasakan paling sukar, sehingga jika ingin terampil dalam menulis maka diperlukan latihan yang intensif karena keterampilan menulis didapatkan dari hasil latihan dan belajar bukan dari warisan turun temurun. Hal tersebut menyebabkan menulis diajarkan di setiap jenjang pendidikan, mulai SD sampai PT. Selain itu, menulis diajarkan di sekolah, dengan tujuan agar peserta didik mampu mengungkapkan perasaan, sikap, ide atau gagasan kepada orang lain, sehingga melatih proses berpikir peserta didik.

Pembelajaran menulis di sekolah diterapkan dalam beberapa mata pelajaran, seperti dalam pembelajaran menulis teks negosiasi. Teks negosiasi merupakan teks yang isinya berupa interaksi sosial untuk mencapai kesepakatan bersama antara pihak yang satu dengan pihak lain. Tujuan utama dari negosiasi ialah untuk menyelesaikan sebuah permasalahan dan menghindari kerugian dengan menyatukan berbagai pendapat dari masingmasing pihak agar tercapai kesepakatan bersama yang saling menguntungkan.

Pembelajaran teks negosiasi dalam kurikulum 2013 diajarkan/diberikan di jenjang Sekolah Menengah Atas (SMA). Materi teks negosiasi baru hadir pada kurikulum 2013 dengan pembelajaran khusus materi teks negosiasi. Karena materi negosiasi baru hadir di kelas $\mathrm{X}$ yang menggunakan kurikulum 2013 materi tersebut cukup sulit dipelajari oleh siswa. Materi yang cukup sulit serta penggunaan pendekatan pembelajaran yang tidak sesuai mengakibatkan kreativitas siswa menulis teks negosiasi dengan bahasa dan struktur teks negosiasi yang baik masih rendah, sehingga menyebabkan pembelajaran teks negosiasi kurang efektif. Hal tersebut merupakan masalah yang perlu dicari jalan keluarnya karena berpengaruh terhadap kemampuan siswa dalam pembelajaran menulis.

Sehubungan dengan hal tersebut, pembelajaran menulis teks negosiasi perlu dikembangkan. Dilihat dari tujuan materi negosiasi diajarkan di SMA adalah agar siswa dapat belajar untuk memecahkan permasalahan layanan publik. Maka, cara yang dapat digunakan untuk mengembangkan kreativitas siswa dalam pembelajaran menulis teks negosiasi yaitu dengan menggunakan pendekatan kontekstual. Penerapan pendekatan pembelajaran ini diharapkan dapat meningkatkan efektivitas pembelajaran menulis teks negosiasi, karena pendekatan ini memberikan kesempatan kepada siswa untuk meningkatkan keterampilan dalam mengelola sumber informasi, belajar mengambil informasi dan menunjukkan pengetahuan yang dimiliki, kemudian dihubungkan atau diimplementasikan dengan dunia nyata.

Berdasarkan hal-hal di atas, tulisan ini disajikan. Tulisan ini membahas (1) penerapan pendekatan kontekstual pada pembelajaran menulis teks negosiasi, pada siswa kelas X SMK Negeri 1 Bojongpicung dan (2) efektivitas pendekatan kontekstual pada pembelajaran menulis teks negosiasi, pada siswa kelas X SMK Negeri 1 Bojongpicung.

\section{METODE PENELITIAN}

"Metode penelitian diartikan sebagai cara ilmiah untuk mendapatkan data dengan tujuan dan kegunaan tertentu" (Sugiyono, 2014:3). Metode penelitian yang digunakan adalah quasi experiment dengan jenis desain yaitu One group Pretest-Posttest Design. Karena itu, rancangan eksperimen dilakukan pada satu kelompok eksperimen saja tanpa kelompok pembanding. Desain ini digunakan 
karena penelitian ini bertujuan untuk mengetahui pengaruh penggunaan pendekatan kontekstual pada pembelajaran teks negosiasi dengan cara membandingkan hasil belajar siswa sebelum diberikan perlakuan dan sesudah diberikan perlakuan.

"Populasi adalah wilayah generalisasi yang terdiri atas objek dan subjek yang mempunyai kualitas dan karakteristik tertentu yang ditetapkan oleh peneliti untuk dipelajari dan kemudian ditarik kesimpulan" (Sugiyono, 2014:117). Populasi penelitian ini adalah siswa kelas X SMK Negeri 1 Bojongpicung tahun ajar 2016/2017 sebanyak 15 kelas yang terdiri dari enam jurusan. "Sampel penelitian adalah sebagian atau wakil dari populasi yang diteliti” (Arikunto, 2010:174). Sampel penelitian yang dipilih adalah kelas X ATPH 1 yang berjumlah 28 orang.

Teknik pengumpulan yang digunakan untuk memperoleh data yaitu teknik tes, observasi dan angket. Teknik tes digunakan untuk mengukur keterampilan peserta didik menulis teks negosiasi sebelum dan setelah menggunakan pendekatan kontekstual. Kuesioner (Questionnaire) atau angket, merupakan serangkaian (daftar) pertanyaan tertulis yang ditujukan kepada peserta didik (dalam penelitian: responden) mengenai masalahmasalah tertentu, yang bertujuan untuk mendapatkan tanggapan dari peserta didik (responden) tersebut (Nurgiantoro, 2010:91).

Kuesioner diberikan setelah perlakuan (penerapan pendekatan kontekstual) diterapkan pada pembelajarn menulis teks negosiasi. Tujuannya untuk mengetahui respon peserta didik terhadap penerapan pendekatan kontekstual dalam pembelajaran menulis teks negosiasi. Teknik observasi digunakan untuk mengetahui aktivitas belajar peserta didik ketika diterapkan pendekatan kontekstual.

"Instrumen penelitian adalah alat atau fasilitas yang digunakan oleh peneliti dalam mengumpulkan data agar pekerjaannya lebih mudah dan hasilnya lebih baik, dalam arti lebih cermat, lengkap, dan sistematis sehingga lebih mudah diolah" (Arikunto, 2010:203).

Instrumen yang digunakan dalam penelitian ini adalah Lembar Kerja Siswa (LKS) berupa tes menulis teks negosiasi, lembar angket yang berisi 10 pertanyaan dengan 4 alternatif jawaban dan lembar observasi yang berisi 15 pernyataan dengan 4 alternatif jawaban. Untuk instrumen tes, sebelum diberikan kepada peserta didik instrument tersebut diuji validitas dan reliabilitasnya terlebih dahulu.

Menurut Arikunto (2013:211) validitas adalah suatu ukuran yang menunjukkan tingkattingkat kevalidan atau kesahihan suatu instrumen. Instrumen yang valid berarti alat ukur yang digunakan untuk mendapatkan data (mengukur) itu valid. Menurut Sugiyono (2013:173) Valid berarti instrumen tersebut dapat digunakan untuk mengukur apa yang seharusnya diukur. Uji validitas dalam penelitian ini dilakukan dengan menggunakan bantuan aplikasi Anates Versi 4.0.5. Hasil perhitungan dengan aplikasi Anates tersebut diinterpretasikan dengan tingkat keandalan koefisien korelasi yang telah ditentukan. Menurut Arikunto (2010:221) "reliabel artinya dapat dipercaya, jadi dapat diandalkan. Reliabilitas merupakan alat untuk mengukur sejauh mana alat ukur yang digunakan dapat dipercaya. Uji realibilitas pada penelitian ini menggunakan bantuan aplikasi Anates Versi 4.0.5.

Setelah dilakukan pengumpulan data, selanjutnya dilakukan analisis data. Menurut Sugiyono (2014:207) "analisis data merupakan kegiatan setelah data dari seluruh responden atau sumber data lain terkumpul". Sedangkan menurut Arikunto (2013:278) "analisis data adalah pengolahan data yang terkumpul dari hasil pengumpulan data". Berdasarkan pendapat tersebut analisis data merupakan kegiatan mengolah seluruh data yang telah terkumpul.

Dari pengolahan data tersebut akan diketahui keberhasilan dalam penelitian yang 
dilakukan. Karena itu, pengumpulan data dan analisis data saling berkaitan satu sama lain. Analisis data digunakan sebagai panduan dalam menganalisis data hasil penelitian dalam pembelajaran menulis teks negosiasi. Analisis data dibagi menjadi tiga, yaitu analisis data hasil angket, hasil observasi, dan analisis hasil belajar.

Data hasil angket dianalisis dengan dengan langkah-langkah sebagai berikut. (1) Mengklasifikasikan setiap jawaban yang sama. (2) Menjumlahkan setiap jawaban yang sama. (3) Memasukan setiap jawaban ke dalam tabel. (4) Mempersentasekan setiap jawaban. (4) Mendeskripsikan persentase jawaban dengan mengacu kepada pedoman penafsiran yang sudah ditentukan.

Data hasil observasi dianalaisi dengan langkah-langkah. (1) menjumlahkan skor setiap jawaban. (2) Mempersentasekan setiap jawaban. (3) Mendeskripsikan persentase jawaban yang mengacu pada kriteria penilaian yang sudah ditentukan.

Untuk data hasil pembelajaran dianalisis menggunakan uji normalitas dan uji hipotesis. Pengujian normalitas menggunakan uji Kolmogorov-Smirnov. Untuk mengujinya dibantu dengan program SPSS versi 20 sedangkan untuk menguji hipotesis digunakan rumus Uji-t. Untuk mengetahui harga $\mathrm{t}_{\text {-hitung }}$ digunakan rumus dari Suharsimi Arikunto sedangkan untuk mencari harga $t$ tabel menggunakan T-tabel.

\section{HASIL PENELITIAN}

Hasil penelitian menunjukkan perta$m a$, perencanan pembelajaran yang digunakan sudah sesuai dengan kurikulum yang digunakan serta tidak menyimpang dari ketentuan RPP yang telah direncanakan. Kriteria perencanaan pembelajaran menurut kurikulum 2013 dijadikan acuan dalam persiapan pembelajaran. Persiapan tersebut dibuat dalam silabus dan RPP yang meliputi kompetensi inti, kompetensi dasar, indikator, tujuan pembelajaran, materi pembelajaran, pendekatan pembelajaran, metode pembelajaran, langkah-langkah kegiatan pembelajaran, sumber dan media pembelajaran, serta penilaian. Dengan demikian, hal tersebut tidak menyimpang dari ketentuan RPP yang telah direncanakan.

Kedua, lembar observasi digunakan untuk mengetahui aktivitas peserta didik ketika kegiatan belajar dengan menggunakan pendekatan kontekstual berlangsung. Lembar observasi peserta didik berisi 14 pernyataan dan diberi skor pada butir pelaksanaan pembelajaran dengan cara memberi tanda $(\sqrt{ })$ pada kolom skor $(1,2,3$, dan 4) sesuai dengan kriteria 1= Kurang, 2= Cukup, 3= Baik, dan 4= Sangat Baik.

Dari tabel hasil observasi dapat diketahui persentase keaktifan peserta didik kelas X ATPH 1 ketika kegiatan belajar berlangsung yaitu $71,6 \%$. Jika dimasukan ke dalam kriteria penilaian hasil observasi, $71,6 \%$ menandakan peserta didik aktif dan antusias ketika belajar menulis teks negosiasi dengan menerapkan pendekatan kontekstual berlangsung. Dari tabel tersebut juga diketahui berbagai jenis aktivitas belajar benarbenar dilakukan oleh peserta didik, mulai dari kegiatan visual (membaca buku sumber dan memperhatikan guru/teman ketika menjelaskan), kegiatan listening (mendengarkan uraian materi dan mendengarkan pendapat teman), kegiatan writing (mencatat penjelasan guru dan menulis teks negosiasi), kegiatan mental (peserta didik mampu memecakan soal dan memberikan kesimpulan mengenai pelajaran yang telah dipelajari), sampai kegiatan yang terakhir yaitu Emotional activities (peserta didik semangat dan senang mengikuti pelajaran).

Penjelasan di atas membuktikan bahwa dengan menerapkan pendekatan kontekstual dalam pembelajaran menulis teks negosiasi aktivitas belajar peserta didik menjadi baik dibandingkan sebelum diterapkannya pendekatan kontekstual. Hal tersebut dapat mendukung hipotesis bahwa pembelajaran menulis teks negosiasi menjadi lebih baik jika 
diterapkan pendekatan kontekstual dalam kegiatan pembelajarannya atau pendekatan kontekstual efektif menjadikan pembelajaran menulis teks negosiasi menjadi lebih baik jika diterapkan dalam pembelajaran menulis teks negosiasi.

Ketiga, sebelum instrumen penelitian digunakan, instrumen tersebut di uji validitas dan reliabilitasnya terlebih dahulu untuk mengetahui layak atau tidaknya instrumen tersebut digunakan. Dari hasil pengujian validitas menggunakan aplikasi Anates diperoleh 3 butir soal yang memiliki korelasi yang baik. Karena dari hasil perhitungan menggunakan Anates tersebut, ketiga soal memiliki nilai koefisien validitas dengan interpretasi cukup dan tinggi, yang artinya ketiga soal tersebut dinilai valid. Soal no 1 memiliki nilai koefisien validitas 0,405 . Jika diklasifikasikan ke dalam tabel interpretasi koefisien korelasi yang memiliki nilai korelasi $0,40<$ rxy $\leq 0,60$ dinilai cukup valid. Soal no 2 memiliki nilai 0,665. Jika diklasifikasikan ke dalam tabel korelasi maka yang memiliki nilai korelasi $0,60<\operatorname{rxy} \leq 0,80$ validitasnya tinggi. Soal no 3 memiliki nilai korelasi 0,739. Jika diklasifikasikan ke dalam tabel korelasi, maka yang memiliki nilai korelasi $0,60<$ rxy $\leq 0,80$ memiliki validitas tinggi.

Uji reliabilitas dilakukan dengan aplikasi Anates Versi 4.0.5. Hasil yang diperoleh yaitu nilai 0,65 . Berdasarkan hasil perhitungan, koefisien korelasi yang berkisar antara 0,600-0,799 termasuk golongan tinggi. Uji statistika yang digunakan untuk megnguji normalitas data adalah uji KolmogorovSmirnov dengan mengambil taraf signifikasi $(\alpha)$ sebesar 0,05. Kriteria pengujiannya adalah $\mathrm{H}_{0}$ diterima jika nilai signifikasi $>0,05$, dan $\mathrm{H}_{0}$ ditolak jika nilai signifikasi $<0,05$.

Berdasarkan tabel di atas, dapat dilihat bahwa nilai signifikasi data pretest sebesar 0,10 atau $>0,05$, dan data posttest sebesar 0,71 atau $>0,05$. Karena nilai signifikasi dari kedua data tersebut $>0,05$, Ho diterima. Hal ini menunjukan bahwa data hasl pretest dan posttest samasama berdistribusi normal.

Keempat, data hasil belajar diperoleh dari hasil tes yang telah dilaksanakan sebanyak dua kali yaitu tes awal dan tes akhir dalam pembelajaran menulis teks negosiasi yang sesuai dengan struktur dan kadah teks negosiasi yang baik. Tes awal (pretest) dilaksanakan pada hari Rabu tanggal 19 April 2017 dan tes akhir (posttest) dilaksanakan pada hari Rabu tanggal 26 April 2017 di kelas X ATPH 1.

Hasil tes awal dan tes akhir memuat jumlah skor tiap soal dan nilai akhir setiap siswa serta mean atau nilai rata-rata dari kedua tes tersebut. Nilai tersebut didapatkan berdasarkan hasil pengolahan data dengan kriteria penilaian tes keterampilan dan kriteria penskoranya.

Nilai hasil tes awal dan tes akhir kemudian direkapitulasi ke dalam tabel rekapitulasi. Dari hasil rekapitulasi, dapat diketahui nilai rata-rata hasil tes awal (pretest) menulis teks negosiasi sebelum diterapkan pendekatan kontekstual adalah 66,89 . Data nilai rata-rata hasil tes awal tersebut menunjukan kemampuan peserta didik menulis teks negosiasi yang sesuai dengan struktur dan kaidah kebahasaan teks negosiasi belum mencapai hasil yang baik. Dari hasil rekapitulasi juga diketahui nilai terendah hasil pretest yaitu 53 sebanyak 2 orang dan nilai tertinggi 80 sebanyak 1 orang.

Sebagaimana hasil tes awal di atas, nilai hasil tes akhirpun selanjutnya direkapitulasi ke dalam tabel rekapitulasi. Berdasarkan data hasil rekapitulasi, diketahui nilai rata-rata peserta didik dalam menulis teks negosiasi yang sesuai sruktur dan kaidah kebahasaan teks negosiasi setelah diterapkan pendekatan kontekstual sebesar 87,64. Jika dibandingkan dengan nilai rata-rata hasil pretest yaitu 66,89, dapat diketahui selisih diantara keduanya yaitu 20,75 . Hal tersebut menunjukan bahwa setelah pendekatan kontekstual diterapkan dalam pembelajaran menulis teks 
negosiasi yang sesuai dengan struktur dan kaidah kebahasaan,kemampuan peserta didik menulis teks negosiasi berubah menjadi lebih baik. Dari hasil rekapitulasi juga diketahui nilai terendah yang diperoleh pada tes akhir (posttest) yaitu 67 sebanyak 1 orang dan nilai tertinggi 93 sebanyak 11 orang. Selain dimasukan ke dalam tabel rekapitulasi, data nilai hasil pretest dan posttest dimasukan ke dalam tabel persiapan Uji-t.

Berdasarkan hasil perhitungan mencari koefisien dengan menggunakan Uji-t diketahui harga $t_{\text {hitung }}$ pembelajaran menulis teks negosiasi menggunakan pendekatan kontekstual yaitu 17,00. Kemudian diketahui harga $t_{\text {tabel }}$ (terlampir) pada d.b N-1=28-1=27 untuk taraf kepercayaan 0,01 yaitu 2,77 dan untuk taraf kepercayaan 0.05 yaitu 2,05 .

Dari hasil uji-t tersebut dapat diketahui thitung $>$ tabel yang menyatakan $\mathrm{H}_{0}$ ditolak dan $\mathrm{Ha}$ diterima. Ini menunjukkan bahwa terdapat pengaruh yang signifikan dalam pengunaan pendekatan kontekstual terhadap hasil belajar menulis teks negosiasi siswa kelas X SMK Negeri 1 Bojongpicung.

\section{Pembahasan}

Berdasarkan hasil pengujian hipotesis dengan menggunakan uji-t diketahui bahwa Ha diterima yaitu terdapat pengaruh yang signifikan dalam penggunaan pendekatan kontekstual terhadap hasil belajar menulis teks negosiasi siswa kelas X SMK Negeri 1 Bojongpicung. Dengan demikian, hasil pengujian tersebut sekaligus membuktikan bahwa pendekatan kontekstual efektif digunakan dalam pembelajaran menulis teks negosiasi.

Hasil penelitian ditunjang oleh penelitian Istiqomah (2015) dengan judul Penerapan Pembelajaran Kontekstual dengan Media Video pada Pembelajaran Teks Negosiasi Bagi Siswa Kelas X SMA Negeri 1 Batu Tahun Ajar 2015/2016. Hasil penelitian tersebut menunjukkan bahwa menulis teks negosiasi dengan menerapkan pendekatan kontekstual lebih efektif dibandingkan dengan pembelajaran tanpa menerapkan pendekatan kontekstual.

Selain dari hasil uji-t, hasil dari observasi dan pembagian lembar angket juga mendukung pernyataan bahwa pendekatan kontesktual efektif digunakan dalam pembelajaran menulis teks negosiasi, karena respon yang diperoleh dari peserta didik mengenai pendekatan kontekstual cukup baik.

\section{SIMPULAN}

Berdasarkan hasil penelitian tentang efektivitas pendekatan kontekstual dalam pembelajaran menulis teks negosiasi, diperoleh kesimpulan bahwa persiapan pembelajaran menulis teks negosiasi menggunakan pendekatan kontekstual dilakukan dengan menyusun RPP yang berpedoman pada silabus dan kurikulum 2013. Dari hasil penelitian diperoleh data hasil tes awal dan tes akhir yang menunjukan nilai tes awal lebih kecil dibandingkan dengan nilai tes akhir. Nilai rata-rata tes awal 66,89 sedangkan nilai rata-rata tes akhir 87,64.

Aktivitas belajar yang dilakukan peserta ketika diterapkan pendekatan kontekstual dalam pembelajaran menulis teks negosiasi mendapatkan skor 43 dengan persentase 71,6 mendapat predikat peserta didik aktif ketika belajar. Hal tersebut mendukung pendekatan kontekstual efektif diterapkan dalam pembelajaran menulis teks negosiasi. Tetapi efektivitas penggunaan pendekatan kontekstual lebih jelas dibuktikan dari hasil perhitungan menggunakan Uji-t yang menunjukan harga $t_{\text {hitung }}$ lebih besar daripada harga $t_{\text {tabel. }}$ Harga $t_{\text {hitung }}$ adalah 17,00, sedangkan harga $t_{\text {tabel }}$ pada (d.b) $\mathrm{N}-1$ 28-1= 27 untuk taraf signifikan 0.05 yaitu 2,05, yang menyebabkan $\mathrm{H}_{0}$ ditolak dan $\mathrm{Ha}$ diterima.

Dengan demikian dapat disimpulkan penerapan pendekatan kontekstual mempunyai pengaruh yang signifikan terhadap hasil belajar menulis teks negosiasi. Atau dengan kata lain pendekatan kontekstual efektif digunakan dalam pembelajaran menulis teks 
negosiasi, karena setelah diterapkan pendekatan kontekstual hasil belajar menulis teks negosiasi peserta didik menjadi lebih baik dibandingkan sebelum menggunakan pendekatan kontekstual.

Berdasarkan hasil penelitian dan simpulan di atas, saran yang dapat disampaikan dalam penelitian ini adalah sebagai berikut. (1) Pendekatan kontekstual efektif diterapkan dalam pembelajaran menulis teks negosiasi. Oleh karena itu, guru hendaknya memanfaatkan pendekatan ini dalam pembelajaran menulis teks negosiasi yang dilengkpi oleh sumber dan sarana yang lebih bervariasi. (2) Hasil penelitian menunjukan bahwa penerapan pendekatan kontekstual dalam pembelajaran menulis teks negosiasi mempunyai pengaruh yang signifikan terhadap hasil belajar peserta didik. Hal tersebut mungkin dapat berubah jika pendekatan tersebut diterapkan pada pembelajaran selain teks negosiasi.

Untuk itu, sebaiknya penelitian tentang penerapan pendekatan kontekstual dapat dilanjutkan kembali oleh peneliti lain dengan materi yang berbeda. (3) Pemilihan model pembelajaran yang cocok dengan pendekatan kontekstual juga perlu diperhatikan karena akan memengaruhi keefektifan dan akan berpengaruh langsung pada hasil belajar peserta didik.

\section{DAFTAR PUSTAKA}

Arikunto, Suharsimi. 2010. Prosedur Penelitian Suatu Pendekatan Praktik. Yogyakarta: Rineka Cipta

Dalman. 2011. Keterampilan Menulis. Jakarta: PT Rajagrafindo Persada.

Hosnan. 2014. Pendekatan Saintifik dan Kontekstual dalam Pembelajaran Abad 21. Bogor: Ghalia Indonesia

Nurgiantoro, Burhan. 2010. Penilaian Pembelajaran Bahasa (Berbasis Kompetensi). Yogyakarta: BPFE-Yogyakarta

Sugiyono. $\quad$ 2014. Cara Mudah Menyusun: Skripsi, Tesis, dan Disertasi. Bandung: Alfabeta, cv. 2014. Metode Penelitian Kombinasi (Mixed Methods). Bandung: Alfabeta, cv. 